\title{
ТОM \\ Promised future and possible future: science communication and technology at World's Fairs and theme parks
}

\section{Susana Herrera-Lima and Daniela Martin Segura}

\begin{abstract}
World's Fairs and scientific-technological theme parks have been propitious places for the communication of science and technology through modernity. This work addresses the issue of the construction of public discourse about the future within these sites, as well as the changing role attributed to science and technology as mediators in the relationships between nature and society. In both fairs and parks, science and technology play a leading role in the construction of the discourse about the desirable and achievable future. The practices of science communication and technology have specific forms, strategies and objectives, depending on the purposes of the discourse enunciators at different historical moments. This is exemplified through two cases: the 1939 New York World's Fair and the EPCOT center in the U.S.
\end{abstract}

Keywords

DOI

Background
Representations of science and technology; Science and technology, art and literature; Science centres and museums

https://doi.org/10.22323/2.17030204
This paper brings together the findings of two research projects addressing the issue of the discourse on the future centered on science and technology, contextualized in exhibition spaces that share some fundamental characteristics as shown below: world's fairs and scientific-technological theme parks. Both are considered as spaces of communication of science and technology, with specific resources and forms of representation and persuasion. In the first research project, universal exhibitions - studied over a long period of time since their appearance in 1851, particularly from the World's Columbian Exposition of Chicago 1893 to the Expo Shanghai 2010 - are defined in methodological terms as visibility, staging and modeling dispositives, in an appropriation of Foucault's formulations about dispositive and discourse [Foucault, 1980].

“Las exposiciones universales se plantean como lugares de comunicación y de representación del contexto sociocultural y de la(s) visión(es) del mundo, desde la perspectiva de un conjunto de actores dominantes en un momento histórico específico. Se han caracterizado como espacios de corte 
museográfico, de naturaleza efímera, que reflejan a modo de espejo multifacético el devenir mundial" [Herrera-Lima, 2016, p. 14]. ${ }^{1}$

In the second research project, which concerns scientific-technological theme parks, the "dispositives" and their proposed definition are addressed through the symbolic forms that constitute them, within the framework of the global cultural industries.

World's fairs and theme parks as places of science communication
The theme parks of the second half of the $20^{\text {th }}$ century are one of the legacies of the Universal Expositions of the United States (World's Fairs) of the inter-war era [Rydell, Findling and Pelle, 2000; Schrenk, 2010]. The World's Fairs of that period played a strategic role in shaping the "world of the future" which President Franklyn D. Roosevelt wanted to intentionally configure in order to have the American nation regain confidence in the face of the effects of the Great Depression and the general crisis after the first World War. The bureau which organized the Fair invited the most prominent designers of the country to create spaces in which modern America appears associated with industrial design, advertising and consumption [Rydell and Burd Schiavo, 2010].

The exhibition strategies that had been used in expositions of previous periods, both in Europe and in the United States, evolved to create exhibitions capable of hooking visitors into immersive tours, absorbing them en masse with permanent sensory inputs. The theme parks of the second half of the $20^{\text {th }}$ century in the U.S. replicated this strategy in the design of the content and discourse of the exhibitions [Schrenk, 2010], updating the role of advertising and consumption in the social dynamics and distributing spaces as in World's Fairs: the nations and their symbols grouped in one area, whereas the corporations with their processes and products were shown through tours and attractions that appeal to the senses and emotions.

In both cases, science and technology play a leading role in the construction of the discourse and the proposal of a desirable and attainable future. The communication practices of science and technology acquire particular forms and strategies, with specific objectives subordinated to the persuasion intents of the creators of the spaces and of the enunciators of the discourse that sustains them. Performances and entertainment are used strategically, showing scientific knowledge and technological developments as the main means to build and achieve the desired future. In the Fairs of the interwar period held in the United States, the science that prevails in the exhibitions is associated to technological development and increasingly linked to industries and companies, which in this period become the main players in the North American exhibitions [Rydell, Findling and Pelle, 2000]. The technological artifact - a product of scientific advances represented by household appliances, industrial machines, automated production processes, and automobiles in particular ${ }^{2}$ - becomes the great representative of the desired future

\footnotetext{
${ }^{1}$ Translator's note: “Universal exhibitions are presented as places of communication and representation of the socio-cultural context and of the vision(s) of the world, from the perspective of a number of dominant players at a specific historical moment. They have been characterized as spaces with a museographic blueprint - and an ephemeral nature - which reflect the evolution of the world like a multifaceted mirror" [Herrera-Lima, 2016, p. 14].

${ }^{2}$ Motor vehicles had already been featured at previous expositions. However, starting from the world's fairs held in the United States during this time, they are strategically presented as the central element for a new proposed configuration of urban life. This was widely reported on in [Herrera-Lima, 2016].
} 
[Herrera-Lima, 2016]. Thus, the communication of science carried out in such spaces becomes inseparable from the applications of science, whether in the industrial, business or domestic sector, and its relevance is supported by the argument that science is an indispensable condition to reach the future: the world of tomorrow. ${ }^{3}$

Cultural industries are arenas in which cultural, political, social, and even economic battles are fought. These spaces exert influence over the public in order to legitimize a specific message and maintain ideological hegemony on certain topics. With scientific-technological theme parks, the research focused on the issue of the attempt to support an ideology of the future created by various organizations and corporations which promote their own perceptions of this subject and legitimize it through scientific-technological messages. The EPCOT theme park at Walt Disney World Resort in Orlando, Florida, was chosen as a case study because of its hybrid nature crossing a leisure and vacation space, a science and technology museum, and a World's Fair. The goal was to identify and analyze the park's scientific-technological discourse in order to report on the construction of the symbolic forms of the future through the narrative resources and specific socio-historical conditions of a cultural industry like the Walt Disney Company.

At EPCOT, science is represented as an instrument to improve the quality of life of people through technological innovations in the field of communication and mobility, as well as through palliative measures to tackle the undesired effects the socalled progress has brought with it, such as pollution and global warming. As with expositions, this theme park resorts to the spectacularization of its narratives in order to support the acceptance of the future it proposes as a desired one. On the other hand, the influence of the corporations that sponsor the attractions is very visible and, in most cases, the narrative acts as an advertising and/or propaganda medium.

Expositions and theme parks: science, technology and future
The aspects converging in the subjects of both investigations - universal expositions and scientific-technological theme parks - essentially concern the placement of proposals for models of the world that integrate rhetorical, visual and kinesthetic resources in which science and technology play a leading role, especially as mediators of the society-nature relationship, and the construction of a discourse on a desired future that is attainable through scientific and technological development.

As illustrated below, the narratives and practices typical of both types of facility hold such desired and attainable world of the future as a pillar of their communication: they present scientific and technological development as a means to achieve it. The resort to immersive and spectacular tours to represent this originated from the universal expositions of the interwar era [Gilbert, 1994], and it is an aspect shared by World's Fairs and scientific-technological theme parks alike. In both cases, these are strategies and forms of communication of science and technology to non-specialized audiences, with well-defined objectives and efficiently articulated resources.

"Through these exhibitions [those of the interwar period], perceived as staging, visualization and modeling devices, it is possible to see the fight for hegemony in the way the world is seen, understood, inhabited and even practiced; a way of formulating and imagining the future, and a new way of perceiving and relating

\footnotetext{
${ }^{3}$ Motto of the New York World's Fair of 1939 [Rydell, 1993].
} 
to the natural environment" [Herrera-Lima, 2016, p. 158]. This is the main legacy which the theme parks of the United States - in particular the Disney-owned EPCOT in Orlando, Florida, U.S.A. - would build on in order to "propose and imagine the future" in an environment characterized by boundless entertainment.

For this paper, we selected the cases of the New York World's Fair of 1939 and the Living with the land exhibition at the EPCOT Center theme park, with a view to illustrate the construction and the staging of a narrative - proposed by dominant players in two different historical periods - on the future hinged on scientific and technological progress.

Methodology

The research used a qualitative approach, starting from the analysis of the discourse and symbolic forms. The analysis of the discourse and proposals of meaning on the mediating role of science and technology in the society-nature relationship in the context of universal expositions adopted a theoretical-methodological perspective based on and developed from the proposals by Niels Andersen and Edgardo Castro building on the approaches of Michel Foucault on discourse and dispositive [Andersen, 2003; Castro, 2004; Foucault, 1970]. ${ }^{4}$ Models were developed for the archaeological and genealogical analysis of each exhibition, for its configuration as a dispositive, integrating the sociohistorical conditions in which they took place and their changes over more than 160 years. ${ }^{5}$ In particular, for the NYWF of 1939 the corpus was specially built using first-hand sources: official guides, newspapers available online, websites developed by visitors or their descendants, magazines, video and university archives. ${ }^{6}$

In the case of scientific-technological theme parks, the research adopted the theoretical approach proposed by John B. Thompson [Thompson, 1993; Thompson, 1995] concerning the meaning of the character of symbolic forms and their social contextualization, as well as its methodology, deep hermeneutics. The investigation was divided into three stages: (1) a sociohistorical analysis of the company, the park and each of the four selected attractions; (2) a formal discourse analysis of the four attractions on five levels (intentional, conventional, structural, referential and contextual) as well as along two analytical axes: the future and science and technology; and (3) an interpretation/reinterpretation of the information gathered.

The following sections present the findings of the analysis, featuring two cases selected among those that were addressed. Specifically, the last section presents the analysis of the relationship between the proposals for the future put forward by the narratives identified at both sites, particularly on the role attributed to science and technology in the mediation between society and nature.

\footnotetext{
${ }^{4}$ Cfr. [Herrera-Lima, 2015].

${ }^{5}$ The three analytical models address the mediating role attributed to science and technology in the relations between society and nature at specific historical moments as an integral element of the regimes of truth that support the discourse and the corresponding discursive formations, as well as the representations in different genres and formats at the expositions. The models correspond to the moments of constitution, configuration and readjustment of the dispositive, based on Castro's formulations derived from Foucault [Herrera-Lima, 2016].

${ }^{6}$ The full corpus on the New York World's Fair of 1939 may be consulted in [Herrera-Lima, 2016].
} 
The world of tomorrow at the NYWF of 1939
The aim of the WFs of the interwar period, starting from the first held in Chicago in 1933, was to showcase the U.S.A. as a modern nation with its own identity, redefining its role on the international stage and distinguishing it from the European countries. It is precisely at the NYWF that the Roosevelt administration, in alliance with the major North American corporations, decided to consolidate such intentions through the design and the construction of a "new world of tomorrow." In this world of tomorrow, science and technology were playing the lead in the preparation of new horizons and the creation of hope in the future.

The Fair's proposed discourse is built around the future and the new world: the pavilions and exhibitions did not show the scientific and technological advances reached up to that moment, but those that would transform all aspects of social life. The plan was to design an orderly world, a society configured around the consumption of technological artifacts, in a mass production environment. The American city of the large highways and suburbs, featuring the car as a symbol of social success, was conceived and developed precisely at the NYWF of 1939 [Mason, 2001]. Its completion, however, would have to wait until after the Second World War.

The U.S. government and the American companies are the main stakeholders of the fair and the enunciators of the discourse intentionally inserted in the fairground and its components. The future and the new - as central discourse elements strategically articulated in the WF device - become the great merchandise on display. The design is used not only as a strategy of representation and distribution of the fairground, but also as an intervention strategy for the transformation of multiple aspects of social life. Applied science - oriented towards the production of consumer goods - plays a fundamental role in shaping the great promise of the future offered here. It is showcased as the foundation and legitimization of technological innovation, the exhibitions rest on the ideological strength of science, using it explicitly in their narrative, with the purpose of re-enchanting and persuading.

The Transportation, Communications, Community Interests, Production and Distribution Zones consisted of corporate pavilions hosting spectacular exhibitions which showcased the benefits of applied science and its repercussion in all spheres of everyday life. The increasingly technical and scientific character of food production processes - already seen in its incipient stage at the Chicago Exhibition of 1893 - is intensified and explicitly shown at the NYWF; one of the highlights is the exhibition on milk production with a sample of actual living cows in the Rotolactor, a carousel in which they are dipped, dried and mechanically milked [Monaghan, 1939]. The pavilions of the oil, electricity and gas companies - Electrical Products, Gas Exhibits, Inc. or Petroleum Industry — showcase the processes of energy production and lighting, which, through scientifically supported processes, would go on to become essential goods for social life.

The coherent and homogeneous discourse on the role of science in the world of the future which was presented at the NYWF is the result of fierce debates, derived from the conflict between academic scientists on the one hand and corporate scientists on the other. The former promote a non-commercial type of science, with a view to produce knowledge to the benefit of humanity and at the service of the formation of rational thought, to support democracy and its values. On the contrary, the research of the latter is carried out in corporate laboratories and is pushed by the development of processes and products required by companies. 
Indeed, businesses promote science as a creator of new and "magical" merchandise, selling a comfortable and preferably de-ideologized future, based on the assumption that science and technology must be aimed at building a pleasant future for the American society, to be achieved through the production and consumption of automobiles, high-speed roads, synthetic materials and household appliances [Kuznick, 1994; Herrera-Lima, 2016].

Entertainment, science and technology are strategically and spectacularly articulated in the pavilions of large companies: a robot and a human voice synthesizer are presented for the first time; home appliances are presented through contests for housewives, with comedy sketches which will become the forerunners of commercial adverts on TV. The automobile is a protagonist in the pavilion of General Motors, which would develop immersive spaces, large-scale models, dioramas and short films to showcase the future with the design of the American city of the 1960s [Monaghan, 1939; Rydell, Findling and Pelle, 2000; Wood, 2003; Findling, 2008]. The political discourse was eradicated from the fair, and with it were the ambitions of scientists to raise awareness through the popularization of science.

At that time, the issue with nature - for society in general and for science in particular - was no longer dominating it: it was taken for granted that it was subdued and controlled by then. In the conflict over the social meaning of science, what is at issue is the orientation of the mediation of science and technology in the announced, and strategically offered, future for the whole world: the battle is fought to gain a privileged symbolic position in the social imagery with respect to the role of science in the global evolution.

Applied science now aims to synthesize nature. From its original role in the industrialization processes as a source of natural resources, nature would also become a supplier of raw materials for new materials. The increasingly technical and scientific transformation of nature was proposed by the scientific research facilities of companies as an indispensable element to improve the life of humans in all respects.

The prominence of the processes of transformation of natural materials through the intervention of science has its most impacting long-term expression in the feasibility of the design and development of new materials, produced from natural elements, the configuration and molecular structure of which has, however, no precedent in nature. This period witnesses the transition from the scientific transformation of nature (the knowledge and the control of it, as well as the systematization of its intervention and use) to the creation of "another nature" through technology (the creation of new materials from synthesis). The emergence of 'the synthetic' as a symbol of progress and a promise of economic and social prosperity, the promotion of the abolition of 'the natural' in materials for domestic use - clothing, furniture, cars - and also in industrial processes, as something desirable, allows for the appearance of the notion of a world without limits, in which the great discovery lies in generating materials which did not exist before.

In An Intellectual History of the 20th Century, Peter Watson quotes an article of the New York Times from that time to show the importance that is attributed to a synthetic material like nylon in the transformation of the relationship with nature [Watson, 2007]. Nylon was introduced by DuPont in The Wonderful World of Chemistry, at the NYWF of 1939: 
“El nailon es diferente, pues no cuenta con ningún referente químico natural [...] Supone... un control tan perfecto sobre la materia que hará que los hombres no necesiten depender por completo de los animales, las plantas y la corteza terrestre para obtener alimento, vestidos y material estructural" [citado en Watson, 2007, p. 371].

The imagined world of the 1960s which General Motors presents in the exhibition entitled 'Futurama' highlights the possibility of creating new materials allowing for the production of a wide and unlimited range of goods. The metaphor of "the highways of research and exploration" links these statements to the narrative thread of the short film To New Horizons, screened at the Highways and Horizons pavilion, which places the automobile and the roads at the heart of the social transformation of the world of the future. ${ }^{8}$

All of the new highways of research and exploration have brought to us more raw materials, new raw materials, new combinations of raw materials, new and greater productivity of the soil, making more plentiful and ever widening range of goods [General Motors, 1940].

The segment of the short film showing a modern farm associates scientific research with risk control in agriculture, and predicts a "1960 world" in which physics and chemistry will be there to help farmers in the transformation of the nature. ${ }^{9}$

Here is a modern farm, the farmer of 1960 works in greater security, for science and research have helped him to control many of the risks of agriculture [...] science even influences pollination by artificial feeding. Does this seem strange, unbelievable? Remember, this is the world of 1960 and physics and chemistry have joined hands with the farmer in helpful friendship [General Motors, 1940].

In this narrative, science plays a part in the improvement of social life also through the control of natural elements and processes, which suitably makes nature all the more distant: for example, in the promotion of pest control with insecticides and poisons in agriculture as well as at home, or in the creation of hygienic food products, packaged and capable of being preserved in the long term. ${ }^{10}$

These orientations of the role of science towards synthetic creations and the control of natural processes are evident in the material exhibited at the NYWF, but also in articles and advertisements appearing in the press and magazines of the time, such as National Geographic. ${ }^{11}$

\footnotetext{
${ }^{7} \mathrm{TN}$ : "Nylon is different, as it does not have any natural chemical reference [...] It implies... such a perfect control of matter that men will therefore cease to rely completely on animals, plants and the earth's crust to obtain food, clothing and structural material" [quoted in Watson, 2007, p. 371].

${ }^{8}$ The Futurama exhibition diorama which is shown in the short film To New Horizons was designed for General Motors by then-renowned designer Norman Bel Geddes. Both, the exhibition and the short film, were part of the GM'S pavilion "Highways and Horizons."

9 "The improvement of humanity through advances in scientific technology" had already been put forward as an objective from A Century of Progress Exposition in Chicago 1933 [Schrenk, 2010, p. 24].

${ }^{10}$ The emphasis was not on the nutritional value of food, but on the efficiency of the processes, on the increase and improvement of production and distribution figures.

${ }^{11}$ In November 1939, the National Geographic Magazine published the article "Chemists make a new world", stating that men were creating a world of artificial items that would allow them to be independent from mother nature [Simpich, 1939, November 1939 issue].
} 
The alliance between science and corporations provides the keys to the realization of a synthetic nature: the advances in chemistry allow for the creation of polymers, physics penetrates into the core of matter, and corporations define the directions to follow in scientific research. 'The synthetic' and 'the artificial' define themselves as possible narrative objects in the discourse domains of the time, giving rise to qualitative transformations in the forms of perception and relation with the natural world, putting together the feasibility of generating elements based on the scientific development with the convenience of its application and distribution by corporations.

El discurso de la articulación virtuosa para el mundo corporativo de ciencia, tecnología y consumo en el espacio de las prácticas sociales gana la disputa por el predominio de una forma de concebir y promover el sentido social de la ciencia, primero en Estados Unidos y después en el resto del mundo occidental [Herrera-Lima, 2016, p. 207]. ${ }^{12}$

The transformation of the future - its design, manufacture and sale - is exhibited at a historical moment in which the contemporary environmental problem is in its initial stage, finding its foundation in the promotion of the unlimited consumption of resources and the development of fossil fuel-based industries and vehicles, together with the ecosystem imbalance that industrial processes would trigger, waste generation, and the intervention on natural processes through design and synthesis. The limited scientific knowledge of that time could not yet give rise to concerns about the limits or irreversible deterioration that carbon emissions or fertilizers and insecticides would cause, or about the generation of indestructible and contaminating garbage, in volumes and scopes that could not even be imagined then, caused by the manufacture of non-biodegradable materials. The concern for the effects of such processes on nature had not settled in the social imagery yet, and was not part of the discursive formation of the time. ${ }^{13}$

The case of Living with the Land
EPCOT is one of the four theme parks that make up the tourist resort Walt Disney World located in Orlando, Florida. This park focuses on science and technology as catalysts of a better future and on the cultural diversity of the planet. As part of the research conducted, four attractions at EPCOT were considered in order to analyze the symbolic construction of the future in the scientific-technological discourse presented to the public; this section reports the findings on the attraction entitled Living with the Land.

Since its inauguration in 1982, Living with the Land has undergone a few subtle modifications, coinciding with changes in the sponsorship, which are important to understand the influence of sociohistorical conditions on the discourse of the attraction. From its opening until 1993, the attraction was entitled Listen to the Land, a name that, unlike the current one, did not imply any involvement with nature other than listening.

\footnotetext{
${ }^{12} \mathrm{TN}$ : The narrative of an articulation virtuous for the corporative world of science, technology and consumption in the space of social practices wins the dispute over the predominance of a way of conceiving and promoting the social meaning of science, first in the United States and then in the rest of the western world [Herrera-Lima, 2016, p. 207].

${ }^{13}$ In the first half of the $20^{\text {th }}$ century, the preservationist and conservationist movements in Europe and the United States were focusing on other concerns [Stradling, 2004]. Environmentalist movements would only emerge after the war, together with the "environment" as a discursive object.
} 
In those days, the tour began with a scene called Symphony of the Seed, which aimed at reminding the audience that all life on the planet "is based on the miracle of green plants" [Beard, 1982, p. 61]. Then, the boat used to travel through four biomes representing a rainforest, a desert, the prairie and a traditional American farm. Then, - as nowadays - visitors entered a room in which pictures depicting past and future agricultural technology were screened. Finally, the boat moved through a greenhouse, described as "a living demonstration of modern agriculture" [Beard, 1982, p. 61]. In 1993, when the contract with Kraft expired, its main competitor - the Swiss company Nestlé - took over the sponsorship of the attraction with the aim of contending for the market of processed foods in the United States.

Two of the major updates in the tour were the change in its title to Living with the Land and the replacement of the initial scene with the simulation of a forest in the middle of a thunderstorm to illustrate how the forces of nature that shape the land can appear destructive to us [Pedersen, 2011]. The following decade emphasized the importance of carrying out activities with some control of the environmental impact, always seeking sustainable development through a strategic cooperation alliance between the key sectors of the cities and the States. In such a context, the change in the title of the ride made more sense: the relationship of humans with the planet should be bilateral, in an attempt to preserve the natural environment while taking advantage of its resources.

In early 2009 - after 16 years - Nestlé decided to terminate the contract with Disney, leaving Living with the Land without sponsorship for almost two years until the company Chiquita Brands International took over in 2011. Since the Nestle days, the narration of the ride has remained unchanged, promoting a view of the future in which technological innovations will not only make it possible to make the most of natural resources, but they will also mitigate the environmental impact of agricultural activities.

Although at the beginning its focus was more on awareness - with its title including the word listen - currently the ride focuses on the complex relationship of man with nature, and on how such relationship can be mutually beneficial. On the other hand, Living with the Land is the only ride within the park in which the work scientists are carrying out at the facilities has always been seen hands-on, incorporating the production of knowledge and the implementation of technology as an element of the entertainment strategy of the ride.

It is important to recall the fact that in the early $20^{\text {th }}$ century "there was a total lack of concerns about the finiteness of resources or any type of secondary effect on nature itself arising from the growing intervention on processes of transformation and synthesis from natural elements" [Herrera-Lima, 2016, p. 207]. Clearly, the path to the inclusion of concerns about the environmental impacts of "progress" into the discourse of exhibition spaces that once disregarded such subject - like the World's Fairs that led to the creation of EPCOT — has been a very long one. Whereas science and technology were once at the service of the nation's development with the ultimate goal of achieving economic prosperity and a dominant position on the world scene, in Living with the Land they are at the service of the protection of the planet. While at the 1939 World's Fair the aim was to differentiate the natural world from the artificial one, this attraction attempts to fill this gap by intrinsically linking all the efforts of agricultural technology with the inherently natural processes of production. 
Initially, the tour explains how food production methods have had impacts, sometimes overlooked, on the environment, and how advances in science and technology are helping to make production more efficient while mitigating these harmful effects. This pro-environmental theme underpins the whole ride, as does the continuous reference to scientific and technological advances in the agricultural area. The objective of the tour is - as stated in the narrative - to learn to live with the land, discovering better ways to harvest food while ensuring the well-being of humans and the environment alike. In this sense, science and technology - seen in action - can legitimize this message and reinforce the idea of a progress under construction through innovations in the agricultural field. This is what the ride is about: the benefits of applied science and its repercussions in various spheres of daily life [Martin, 2016].

However, it should not be overlooked that the domination of nature by man remains a key point of the future foreseen by this attraction, despite the rhetorical attempts to emphasize an equitable relationship between the two. Through an analogy, it could be said that the ride is not so different from a circus with animals. At the beginning, the circus shows how indomitable a lion can be, for example. In this case, there is a sample of natural events like a big storm. Then, the tamer appears on the scene, gesturing to calm the feline down. Here, that role is played by the scientist, a pacifier of nature, in the setting of a historical journey through agricultural technology. And finally the act ends with the tamer making the lion do what he orders. In the case of the attraction, this is when it exhibits the changes in cultivation methods and even in the shape of the fruits. Even when the importance of sustainability is emphasized, Living with the Land is a sample of man's mastery over nature and his ability to exploit it. Now the word 'command' does not only refer to the exploitation of natural resources - that kind of domination has already been achieved, - but to the control over the effects of said practices.

Now considering the sponsors of Living with the Land, the attraction has been used to outline an environmental discourse projecting a positive image of companies that were or still are sources of serious environmental damage: Nestlé, which has had to face allegations of unethical marketing, contamination and even child slavery [Andrei, 2017]; and Chiquita Banana, accused of indiscriminate use of pesticides and the deforestation of tropical forests. In this sense, The Walt Disney Company has essentially legitimized companies whose productive activities are inconsistent with the underlying message.

Another important aspect is that the entire narrative tends to stress the idea of $u s$, understood as those who work at or for Disney, not as the human species in general. The "us concept" is stressed over and over through positive statements such as "[...] we can save millions of gallons a year" or "[...] we are reducing the use of conventional pesticides" or "[...] some of our best ideas are inspired by nature." According to this narrative, the player behind such innovations is not only a Disney-us, but also a concept of $u s$ which exclusively includes the American people. This nationalism is reinforced throughout the tour by not mentioning any other player that might be conducting further research to substantiate the cultural, symbolic, economic, scientific and technical capital not only of the company, but of the entire country. This means that, whereas the achievements of the scientific and technological innovations being developed are obviously critical, the future proposed is delineated in terms of a typically American individualistic entrepreneurial spirit. 
Although this attraction could count on foreign sponsors since the beginning, it has proved to be one of the most nationalistic of the park. Its discursive strategy is reminiscent of the one used by the government of the United States during the Second World War to instill ideology through propaganda, which was brought to the public through forms of entertainment - such as Disney. Therefore, rather than supporting a harmonious relationship between the human race and the planet, its message apparently suggests that Americans are the best at taking care, and also advantage, of the planet's resources, acting as mediators - and owners - of the exploitation practices and their products. It is a dominant discourse that reinforces the country's symbolic authority in terms of scientific-technological innovations.

As for agricultural technology, the attraction presents several innovations with their effects, such as a pesticide management program, vertical farming and hydroponic systems. In this sense, Living with the Land is one of the few attractions keeping EPCOT's original vision alive: developing technology, using it inside the park and later introducing it to the free market. The agricultural innovations presented are promoted as they enable greater production with fewer resources and with little environmental impact. However, there were no official reports confirming that any invention developed at the site is being used somewhere else. It could be assumed that, in fact, the technology developed in the facility is already part of a fruitful market, since nature is presented as a commodity.

Living with the Land represents the aim Walt Disney was pursuing with his early ideas on EPCOT and what Card Walker, president of The Walt Disney Company from 1980 to 1983, would later describe as one of the park's objectives: to demonstrate how new technologies and ideas can be applied in a practical way to improve the quality of life of communities in the United States (America) and in the world [Crawford, 2015]. While it is not clear whether these innovations are used outside the park — some authors such as Wilson [1994] claim this has only benefited multinational companies, - they are presented to the public as practices that are already being implemented, at least in the vicinity of EPCOT.

Sponsorships serve as a way to acclaim, strengthen and exert a symbolic type of power based on progress, for which EPCOT has turned into "a vehicle for the introduction and consolidation of cultural hegemony" [Herrera-Lima, 2016, p. 345]. In this specific case, attractions become devices educating and training people to "consume" as they give a taste of how the life of a society can be transformed through the consumption of the exhibited technology. Far from challenging the public, EPCOT aims to gain the trust of visitors, thus increasing the symbolic load of its message and facilitating the creation of a truth to use it with its symbolic power.

\section{Changes and discontinuities in the discourse}

\section{The legitimation of the presence of corporations and sponsorships in the exhibitions}

The illusory reality displayed at the WFs and EPCOT, sold as legitimate, is built on the basis of the ideas underpinning a specific ideology that expresses the interests of the subjects and institutions who can access the resources required to spread it [Thompson, 1995]. Sponsorships have served as a way to acclaim, strengthen and exert a symbolic power based on the idea of progress, which is presented to support the ideology of Western growth and development: a future that reproduces a hierarchical order, with the evident and comfortable absence of any discourse on the violated planet. 
At NYWF, applied science - oriented towards the development of technologies transforming natural environment - acted as the ultimate mediator in the relationship between a society whose culture is based on technological development and consumption and nature, invaded and emulated by synthetic elements. The mass production of goods, non-degradable materials and energy production based on fossil fuels are central elements in the communication of science and technology used at the World's Fair to announce the world of the future.

The delivery of such proposals in the following decades would bring the planetary balance to its limits, which required a change in the narratives on the nature-society relationship, particularly on the mediating role of science and technology within such relationship. This marked the gradual emergence of the environmentalist and ecological discourse, which would be then adopted by social movements and institutionalized within international organizations starting from the 1970s. Both universal expositions ${ }^{14}$ and theme parks adopted and spectacularized this narration, as it has been shown in the case of EPCOT. Not only in Living with the Land, but in other attractions of the park as well, environment protection becomes the new goal for the future, in which the consumption and use of ecological products confer a new social and moral superiority status.

The mediation of science and technology is now oriented towards a supposed harmonious and sustainable relationship, in a discourse that is riddled with gaps and inconsistencies, based on the commodification of nature and practices that, far from fostering this harmony, intensify environmental deterioration.

\section{The relationship between the foreseen future and the possible future}

The construction and selling of the future through scientific and technological development is one of the fundamental characteristics that symbolically unite the WF and the EPCOT park. However, the future that promises "the world of tomorrow" of the interwar period will be challenged years later by the consequences of its own developments: the increasing environmental pollution by greenhouse gases that will have global warming as one of its most serious consequences, the production and massive accumulation of non-degradable waste which converts land and oceans into spaces that are less and less habitable, and the shortage of water suitable for the consumption of living beings, as a result of over-exploitation and industrial pollution, among others. Challenges faced with the discourse of eco-friendly technologies and environmentally friendly products, through various entertainment forms, on the path towards sustainable and harmonious development.

In the contemporary world, the future appears to be less and less easy to delineate with certainty. However, the discourse on the future presented at EPCOT is one of progress without ruptures, without uncertainty and complexity, whose purpose - dictated by corporate interests - is to gain a privileged and exclusively positive

\footnotetext{
${ }^{14}$ Universal Expositions, starting from Sevilla 1992 up to Shanghai 2010, increasingly incorporated the discourse on the harmonious relationship with the environment through the use of eco-friendly technologies. Cfr. [Herrera-Lima, 2016].
} 
symbolic position in the social imagery regarding the role of the science and technology in the world. In this sense, the growing industrialization and global risks are not represented in any of the spaces of the park, as it would mean placing within the reach of the public an undesirable future in an entertainment space.

Translated by Massimo Caregnato

\section{References}

Andersen, N. A. (2003). Discursive analytical strategies. Glasgow, U.K.: The Policy Press.

Andrei, M. (19th May 2017). 'Why Nestlé is one of the most hated companies in the world'. ZME Science. URL: http://www.zmescience.com/science/nestle-comp any-pollution-children/.

Beard, R. (1982). Walt Disney's Epcot center: creating the world of tomorrow. U.S.A.: Harry N. Abrams.

Castro, E. (2004). El vocabulario de Michel Foucault: un recorrido alfabético por sus temas, conceptos y autores. Buenos Aires, Argentina: Universidad Nacional de Quilmes. Prometeo.

Crawford, M. (2015). The progress city primer. U.S.A.: Progress City Press.

Findling, J. E. (2008). Encyclopedia of world's fairs and expositions. NC, U.S.A.: McFarland and Company, Inc. Publishers.

Foucault, M. (1970). La arqueología del saber. Spanish translation by A. Garzón del Camino (2010). México: Siglo XXI editores.

- (1980). 'The confession of the flesh: a conversation'. In: Power/knowledge, selected interviews and other writings, Michael Foucault. Ed. by C. Gordon. New York, U.S.A.: Pantheon Books.

General Motors (Writer) (1940). To new horizons. [Motion Picture]. URL: https://archive.org/details/ToNewHor1940 (visited on 15th November 2017).

Gilbert, J. (1994). 'World's fairs as historical events'. In: Fair representations. World's fairs and the modern world. Ed. by R. Rydell. Amsterdam, Netherlands: VU University Press, pp. 13-27.

Herrera-Lima, S. (2015). ‘Dispositivos de visibilización y propuesta de modelos de mundo: genealogía y devenir del discurso medioambiental contemporáneo en las Exposiciones Universales'. Revista Latinoamericana de Metodología de las Ciencias Sociales 5 (2). URL: https: //www.relmecs . fahce. unlp. edu .ar/article /view/relmecs_v05n02a03/6933.

- (2016). Del progreso a la armonía. Naturaleza, sociedad y discurso en las Exposiciones Universales (1893-2010). Guadalajara, Mexico: ITESO. URL: http://delprogreso.iteso.mx/.

Kuznick, P. J. (1994). 'Losing the world of tomorrow: the battle over the presentation of science at the 1939 New York World's Fair'. American Quarterly 46 (3), p. 341. https://doi.org/10.2307/2713269.

Martin, D. (2016). La construcción simbólica del futuro en los discursos científico-tecnológicos de las industrias culturales: EPCOT como caso de estudio. Tesis para obtener el grado de Maestra en Comunicación de la Ciencia y la Cultura. Tlaquepaque, Jalisco, Mexico: ITESO. URL: http://hdl. handle.net/11117/4339.

Mason, P. F. (2001). 'The building of a superhighway future at the New York World's Fair'. Cultural critique 48 (Spring), pp. 65-97. URL: https://www. jstor .org/stable/1354397. 
Monaghan, F. (1939). Official guide book of the New York World's Fair 1939. New York, U.S.A.: Exposition Publications.

Pedersen, R. (2011). The EPCOT explorer's encyclopedia: a guide to Walt Disney world's greatest theme park. U.S.A.: Epcyclopedia Press.

Rydell, R. (1993). World of fairs. Chicago, U.S.A.: University of Chicago Press.

Rydell, R. and Burd Schiavo, L. (2010). Designing tomorrow. America's world's fairs of the 1930s. Singapore: Yale University and National Building Museum.

Rydell, R., Findling, J. and Pelle, K. (2000). Fair America. Washington, DC, U.S.A.: Smithsonian books.

Schrenk, L. D. (2010). "'Industry applies”. Corporate marketing at a century of progress'. In: Designing tomorrow. America's world's fairs of the 1930s. Singapore: Yale University and National Building Museum, pp. 23-39.

Simpich, F. (1939). 'Chemists make a new world'. In: The complete national geographic. 108 years of national geographic magazine on CD-ROM. U.S.A., pp. 604-607.

Stradling, D. (2004). Conservation in the progressive era. Classic texts. Seattle, U.S.A.: University of Washington Press.

Thompson, J. B. (1993). Ideología y cultura moderna. México: Universidad Autónoma Metropolitana.

- (1995). The media and modernity. Stanford, U.S.A.: Standford University Press.

Watson, P. (2007). Historia intelectual del siglo XX. Barcelona, Spain: Crítica.

Wilson, A. (1994). 'The betrayal of the future: Walt Disney's EPCOT center'. In: Disney discourse. Ed. by E. Smuoodin. U.K.: Routledge, pp. 118-128.

Wood, A. (2003). 'The Middletons, Futurama and Progressland: disciplinary technology and temporal heterotopiain two New York world's fairs'. New Jersey Journal of Communication 11 (1), pp. 63-75.

https://doi.org/10.1080/15456870309367438.

Authors

Susana Herrera-Lima. Professor-researcher at the Department of Sociocultural Studies of the ITESO University, in Guadalajara, Mexico. Ph.D. in social scientific studies. Her lines of research are located at the intersection of public

communication of science with environmental communication, in the specific area of the study of the discourse on the society-nature relationship. She is an advisor for projects in the field of public communication of science on socio-environmental issues. Coordinator and author for the book series Comunicar Ciencia en México, at ITESO. E-mail: shl@iteso.mx.

Daniela Martin Segura. Researcher specializing in communication of science and urbanism. She is a member of a research group called Ensamble and a consultant for governments, universities and international organizations in the field of development planning and management. She is a university lecturer at ITESO, and will soon be part of the NUCLEUS project team at the Rhine-Waal University of Applied Sciences in Cléveris, Germany. E-mail: tapiocatundra@gmail.com.

How to cite

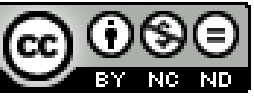

Herrera-Lima, S. and Martin Segura, D. (2018). 'Promised future and possible future: science communication and technology at World's Fairs and theme parks'. JCOM 17 (03), A04_en. https://doi.org/10.22323/2.17030204. 